DOI: https://doi.org/10.32839/2304-5809/2020-78.1-12

UDC 811.111'42

Kulchytska Olena

Ivan Franko National University of Lviv

\title{
ON UNDERSTANDING THE NATURE OF VERBAL AGGRESSION
}

Summary. The article focuses on verbal aggression and its constituents. The study delves both into the elements of aggressive language and its interpersonal consequences. Realization of the verbal aggression nature is essential to raise awareness of this particular type of aggression. Verbal aggression is interpreted as a specific form of verbal behavior aimed at causing harm to other interlocutors. Pejorative language is given as an example of potentially manipulative linguistic means that reflects a state of verbal aggression. The negatively evaluative speech act of aggressive nature, the pejorative one, is studied in the complex with its illocutionary and perlocutionary functions and pragmatic characteristics. The coping strategies and education practices of mollifying/alleviating verbal aggression deleterious effects are outlined.

Keywords: verbal aggression, pejorative, speech acts, coping strategies, education practices.

Кульчицька О.В. Львівський національний університет імені Івана Франка

\section{ПРО ПРИРОДУ ВЕРБАЛЬНОЇ АГРЕСІЇ}

Анотація. У статті висвітлюеться поняття вербальної агресії та її складових. Дослідження заглиблюеться як у елементи вербальної агресії на лінгвістичному рівні, так і в її міжособистісні наслідки загалом. Вивчення мовленневої діяльності через призму сучасних лінгвістичних напрямків - когнітивного, прагматичного, психолінгвістичного - дозволяе розглядати мовні явища, до яких належить і вербальна агресія, не тільки всебічно, але і в динаміці, що зумовлена як прагматикою, так і закономірностями мовленневих процесів з огляду на мовленневе мислення. Дослідження та розкриття характеру вербальної агресії відіграє важливе значення для підвищення обізнаності та усвідомлення суті цього виду агресії, так само, як i для аналітики механізмів їі функціонування у процесі вербалізації негативних емоцій та мовних інтенцій у світлі прагматичних процесів. Сутність вербальної агресії полягає в особливому трансформуванні зовнішніх реакцій на негативні емоційні подразники у внутрішні реакції, пов’язані як 3 розумовою, так і 3 мовною діяльністю. Вербальна агресія трактується як специфічна форма словесної поведінки, спрямована на заподіяння нефізичної шкоди співрозмовнику, прикладами якої є образи, докори, звинувачення, крик, вереск, лайка, погрози та ін. Пейоративні мовні одиниці наводяться як приклад потенційно маніпулятивного мовного засобу, який циркулює навколо стану словесної агресії. Проаналізовано негативно-оцінний мовленнєвий акт агресивного характеру, а саме пейоративний. $\mathbf{Y}$ статті розглядаються ілокутивні та перлокутивні складові мовленневого акту як прагматичні фонкції пейоративного пласту мови. Окреслено основні стратегічні моменти подолання вербальної агресії та освітні практики для пом'якшення чи нівелювання шкідливих наслідків вербальної агресії.

Ключові слова: вербальна агресія, пейоратив, мовленнєвий акт, стратегії подолання, освітні практики.

Droblem statement. There are a lot of things that alienate people, and one of them is aggression. Aggression can be caused by various triggers, from frustration due to blocked goals to feeling disrespected and it is often manifested verbally, and sometimes, it might turn into physical aggression, which could be dangerous and harm both parties. This leads to the need to be aware of the notion of verbal aggression and to make students of different faculties realize what can be done with the spoken (and written) word, as verbal aggressiveness is also a major cause of violence. When verbal aggressiveness escalates, it often turns into physical violence.

Recent research and publications. There is an emerging field investigating language conflicts and language aggression, that is the investigation of hatred as an emotion connected to hate/aggressive speech (Sternberg 2008, Meibeuer 2016); the relationship between adolescents' Internet use and verbal aggression (Appel 2014); verbal aggression strategies linked to different languages (Golod 2009); verbal venting in social webs (Rösner 2016); numerous attempts to balance out free speech, including the right to slur as well as anti-discrimination law (Weber 2009; Haupt 2005; Maitra,
McGowan 2012). For example, the research of language and law aspects in forensic linguistics dealing with a number of issues on aggressive speech and insulting (Hilgendorf 2008) and concerned with the evaluation of the language of aggression as the "words that wound" [3, p. 144]. Journalism, politology, sociology, literature, cinematography and many other spheres of modern life inevitably face verbal aggression.

The purpose of the article is to give the insight into the crucial importance to detect and realize the notion of verbal aggression, along with all its constituents, to present some education practices in the field of teaching the English language, as well as to present some basic coping strategies and to promote non-conflict communication in the interpersonal field.

Presentation of the main material. Social psychologists differentiate between verbal and physical aggression. Aggression includes not only physical and psychological aggression/intimidation, but verbal aggression as well, for example: name-calling, teasing, gossiping, insulting, threatening, shouting, etc., which is defined as a behavior that is intended to hurt or harm others [1, p. 710]. If physical aggression is considered as activity that 
involves harming others physically, nonphysical aggression is considered as activity that includes verbal aggression. Closely related is an emotional aggression - the one that occurs with only a small amount of intent/forethought and that is determined primarily by impulsive emotions, and a cognitive one, which is planned, intentional, more conscious than affective and may be calculating and completely cold. The essence of verbal aggression lies in the particular transformation of external reactions to negative emotional stimuli into internal reactions related to both mental and linguistic activities. It is worth mentioning that the majority of the modern theories recognize aggression as an integral dynamic characteristic of human activity and adaptability, besides, aggression is a way of obtaining a share of a vital resource [9].

The crucial need to detect the interlocutor's signs of verbal aggression, which includes yelling and name calling, blaming and playing victim, shaming and criticizing, abusive 'jokes' usage, dismissing or trivializing interlocutor's feelings, use of threats to intimidate, gas-lighting, and other proved to be helpful in mollifying any type of aggressive communicative acts.

The act of communication includes two or more interlocutors, with their own intentions, moods, types of messages they want or need to share. It is closely connected to speech acts (an utterance defined in terms of the speaker's intention and the effect it has on the interlocutor). These messages can be as follows: physical appearance attacks, character attacks, competence attacks, insults, mockery, scolding, teasing, profanity, threats, and many others. These messages are then verbalized by the words that are negative, loaded with emotions, the ones that express negative evaluation (pejoratives).

Pejoratives are regarded as potentially manipulative linguistic means. The aim of pejoratives is to perform an illocutionary effect and obtain a perlocutionary one via carefully selected speech means. Pejorative vocabulary has a complex, conceptual structure and is characterized by a strongly marked contextual component. Moreover, it possesses emotive micro-components, which correlate with pragmatic principles of speech acts. There are seven emotive micro-components (emosemes) with pejorative meaning, namely: humorous, ironic, disapproving, neglectful, scornful, brutal, and abusive. Communicative, pragmatic and linguistic parameters of pejoration are revealed in their functions: emotive and pragmatic. It is important to add that there is a negative evaluation expressed in speech acts. Hence, one may ask whether there is a pejorative speech-act type. For instance, slurring may constitute such a pejorative speech act [5, p. 68-70]. J. Meibauer assumes that slurring is a subtype of insults, belonging to the class of expressives [7, p. 14]. The classification of pejorative speech acts is by no means easy and one might have to account for subtle distinctions between insulting, slander, slurring, and other types of derogatory utterances. Let us consider the following example:
A: 'Idiot!'
B: 'What do you want?'
A: 'How could you do this?'
B: "It was my decision!"
A: 'Idiot!'

B: 'Of course I talk like an idiot, how else would YOU understand? Asshole.'

In this dialogue a pejorative word Idiot is used by A to insult B. The targeted person B "accepts" A's message by fighting back verbally. "Of course I talk like an idiot, how else would YOU understand? Asshole" shows that the verbal aggression is escalating/developing. Thus, lexeme Idiot contains the emotional component - emoseme with a brutal denotation and the connotation that satisfies A's communicative intent to insult and belittle B. The given negatively evaluative speech act of aggressive nature displays its pragmatic property: illocutionary and perlocutionary functions that are reflected in A's and B's answers. Thus, the A's intention to insult B has been achieved. In the following example we observe another communicative situation (according to J.Meibauer):

A: 'Idiot!'

B: 'What do you want?'

A: 'That is impertinent how you pushed in!'

B: You could have moved to the side, then.'

A: 'Idiot!'

B: 'Do not address to me this way! Please. Anyway, sorry.' [7, p. 13]

In this altercation, a pejorative word Idiot is also used by A to insult B. The targeted person (B) rejects this pejoration by refusing to take part in the communication ("Do not address to me this way! Anyway, sorry"). The verbal aggression is most likely to be over. Despite the presence in lexeme Idiot pejorative emoseme, a perlocutionary effect is not achieved as $\mathrm{B}$ displays reasonable and conscious attitude opting for non-pejorative words (having detected A's verbal aggressive signs) and eliminating this verbal aggression with the neutral words. Thus, B's response is a coping strategy to A's verbal aggression. B acts as a "conflict alleviator", being reasonable and responsible. Once it is achieved the verbal aggression is gone.

Nowadays, it is under rather intense discussion whether and to what extent certain pejorative words, in particular those that target certain populations, should be avoided in children's literature. This relates to scientific talks on linguistic discrimination and also to 'political correctness' and taboo words, and non-juridical norms of political and verbal behavior. These concerns show how important is the notion of verbal aggression [7, p. 11].

Verbal aggression acts primarily as a destructive element in human's life, resulting in problems in family relationships, customer services, everyday interaction, and many other areas of our life [6, p. 5-6]. This leads to the necessity of developing, implementing and popularizing the coping strategies towards verbal aggression in the interpersonal sphere as well as developing educational practices through the prism of the English language acquisition [10, p. 2]. The best coping strategies include:

- Conscious impersonalization. Verbally aggressive people degrade and belittle, demean those around them for numerous of reasons. Once we realize that it becomes easy to "drift away" from the conflict ruminating over the verbal aggressors motives that quite often leads to the feeling of sympathy towards aggressive interlocutor.

- Stop gaps. This strategy is useful when one party of the verbal conflict becomes emotionally 
caught up in it or when they sense that their interlocutor is unable to stop engaging in defiant or aggressive behavior because they are being controlled by their emotions. This technique involves the "conflict alleviator" telling the other party that they both need a break until they are able to tranquilize. This also allows both parties to bring emotions under control and prevent the conflict cycle from escalating.

- Distraction/redirection/humor. These strategies can be used in an altercation, quarrel, disagreement, any crisis situation in order to divert immediately the verbal aggressors' attention from the issue. It permits a temporary reduction in negative feelings and emotions as well as in verbal attacking or aggressive verbal reactions and responses.

Needless to say that there are lots of other coping strategies that are worth getting a closer look at. These coping strategies require practice [2]. They can be very effective in giving both parties of a verbal conflict time they need to tranquilize, to reconsider their verbal communication aims, thus, leading to alleviation of the verbal aggression. In modifying the behavior of a verbal aggressor, it is necessary, as in dealing with any other behavior, to perform a functional assessment before designing and implementing a proactive behavior modification intervention. It requires specific skills, time and practice.

Practices for educators may include the following methods (that can be subdivided into theoretical and practical):

- Lecturing/practical classes in componential analysis of pejorative lexemes, as well as slang words, emotive words, expressives, hybrid lexemes and others.

- Lecturing/practical classes in verbal aggression's nature, including its sources, signs, prevention, etc.

- Linguistic practice of different speech acts.

- Gamification. Role-playing of appropriate responses to various aggressive speech acts. E.g.: mock student-faculty courts (conducting in the disciplinary process student-faculty court to deal with students who have been identified as verbal aggressors/bullies through specific incidents).
- Students' practices establishment as mediators/bystanders in case of verbal aggression speech act occurs with its further reporting and analysis during their classes.

- Developing a universal policy on verbal aggressive behavior of any kind, and its further communication and distribution with subsequent students' regular meetings to monitor the effectiveness of these intervention strategies.

- Usage of cooperative learning for curriculum delivery, usage of stories, creative activities to communicate and promote appropriate social behavior.

- Development and dissemination of the rules/ codes for appropriate social behaviors and their publications on posters/newsletters/memos [4].

These are only some of the ideas that have been singled out as the most interesting and "catching" for both, educators and students.

Conclusion. To conclude with, it is worth noting that we should try to consciously opt for the "right" words in order to eliminate aggression while verbalizing our negative emotions and communicative intentions, though aggression, like any emotion, contains wisdom that points the way towards alignment with our higher selves. Being aware of verbal aggression constituents, coping techniques and strategies will help to embrace it and to deal with it in a healthy way. We share Molly Howard's viewpoint that "it can be hard to wrap our minds around the idea that aggression could be anything but harmful, but the origins of the word offer one little hint about its benefits. From the Latin, ad, toward; and gradi, to step, we can see that the root of "aggression" essentially means "to come forward', which is an encouraging reframe. We don't need to live in fear of our strength or convolute our true feelings. We can embrace our power and use healthy aggression in our everyday lives" [8].

Practical validity of the article is determined by the possibility of developing and applying its highlights into lectures that can be embedded into the courses on pragmatics, communicative and cognitive linguistics, rhetoric, stylistics, text linguistics, discourse analysis, as well as into teaching practice and internships of different faculties.

\section{References:}

1. Crick, N.R., Grotpeter, J.K. Relational aggression, gender, and social-psychological adjustment. Child Development. 66(3), 1995. Pp. 710-722.

2. Defiance and Verbal Aggression... preventing and dealing with challenging behavior. Available from: http://ceed.umn.edu/wp-content/uploads/2017/05/Defiance-and-Verbal-Aggression.pdf

3. Delgado R. Words that Wound: A Tort Action for Racial Insults, Epithets, and Name-Calling. Harvard Civil Rights-Civil Liberties Law Review. Vol. 17. 1982. Pp. 133.

4. Goldstein A.P. Low-level aggression: First steps on the ladder to violence. IL: Research Press. Champaign, 1999.257 p.

5. Kulchytska O.V. Peioratyvy iak zasib verbalizatsii vyrazhennia negatyvnogo emotsiinoho stanu [Pejoratives as a means of verbalization of the negative emotional state]. Science and Education in a New Dimension: Philology. 2014. № II (1), Iss. 17. P. 68-70.

6. Mark A. Hamilton. Verbal Aggression: Understanding the Psychological Antecedents and Social Consequences. Journal of Language and Social Psychology. 31(1):5-12. March 2012. P. 5-12.

7. Meibauer J. Pejoration. John Benjamin's Publishing Company, 2016. 357 p.

8. Molly H. On aggression: seven healthy ways to use your aggressive feelings. Available from: http://www.psychedinsanfrancisco.com/on-aggression/

9. Petryk A.A. Psykholohichni pidkhody vyvchennia verbalnoi ahresii [Psychological Approaches to Studying Verbal Aggression]. Available from: https://labipt.com/psychological-approaches-to-the-study-of-the-phenomenon-ofaggression/

10. Reitman D., Villa M. Verbal Aggression: Coping Strategies for Children. Nova Southeastern University, 2004. P. 1-5. 


\section{Список літератури:}

1. Crick, N.R., Grotpeter, J.K. Relational aggression, gender, and social-psychological adjustment. Child Development. 66(3), 1995. Pp. 710-722.

2. Defiance and Verbal Aggression... preventing and dealing with challenging behavior. URL: http://ceed.umn.edu/ wp-content/uploads/2017/05/Defiance-and-Verbal-Aggression.pdf

3. Delgado R. Words that Wound: A Tort Action for Racial Insults, Epithets, and Name-Calling. Harvard Civil Rights-Civil Liberties Law Review. Vol. 17. 1982. Pp. 133.

4. Goldstein A. P. Low-level aggression: First steps on the ladder to violence. IL: Research Press. Champaign, 1999.257 p.

5. Кульчицька О. В. Пейоративи як засіб вербалізації вираження негативного емоційного стану. Science and Education in a New Dimension: Philology. Будапешт, 2014. № II (1), Iss. 17. P. 68-70.

6. Mark A. Hamilton. Verbal Aggression: Understanding the Psychological Antecedents and Social Consequences. Journal of Language and Social Psychology. 31(1):5-12. March 2012. P. 5-12.

7. Meibauer J. Pejoration. John Benjamin's Publishing Company, 2016. 357 p.

8. Molly H. On aggression: seven healthy ways to use your aggressive feelings. URL: http://www.psychedinsanfrancisco.com/ on-aggression/

9. Петрик А.А. Психологічні підходи вивчення вербальної агресії. URL: https://labipt.com/psychologicalapproaches-to-the-study-of-the-phenomenon-of-aggression/

10. Reitman D., Villa M. Verbal Aggression: Coping Strategies for Children. Nova Southeastern University, 2004. P. 1-5. 